Anna Bartosińska

Uniwersytet Łódzki

\title{
ZACHOWANIA NIEWERBALNE ROZMÓWCÓW W SYTUACJI DIALOGOWEJ (NA PODSTAWIE PROGRAMU DZIEŃ DOBRY TVN)
}

SŁOWA KLUCZOWE: komunikacja niewerbalna, gesty, typologia gestów, telewizja śniadaniowa

\section{Wstęp}

Celem niniejszego artykułu jest zbadanie zagadnienia, jakim jest szeroko rozumiana komunikacja niewerbalna. Bazą materiałową, na podstawie której opracowałam zagadnienie, jest program Dzień Dobry TVN. Do analizy wybrałam tylko niektóre odcinki programu.

Postanowiłam wykazać, iż znaki niewerbalne są nieodłącznym elementem dialogu „twarzą w twarz” i tworzą z mową zintegrowany komunikat. Podejmując ten temat, chcę podkreślić kontekstualne znaczenie gestów oraz opisać funkcje i cele komunikacyjne, jakim te zachowania służą. Analizie poddałam wybrane programy, emitowane od listopada 2010 roku do końca stycznia 2011 roku.

\section{Wyodrębnienie komunikacji niewerbalnej z języka ogólnego}

Zacznę od wyodrębnienia komunikacji niewerbalnej z języka ogólnego. Jej występowanie ściśle wiąże się z odmianą mówioną języka i wynika z faktu, iż w rozmowie język bardzo często nie wystarcza jej uczestnikom do przekazania wszystkich treści. Wówczas komunikacja niewerbalna staje się bardzo ważnym kanałem przekazu informacji.

\section{Wariant oficjalny i nieoficjalny języka mówionego}

Kazimierz Ożóg wydziela w ramach języka mówionego wariant oficjalny oraz wariant nieoficjalny, czyli język potoczny [2006, s. 85-98]. Według niego wariantem oficjalnym posługujemy się w sformalizowanych sytuacjach publicznych lub towarzyskich. Z kolei w kontaktach codziennych, prywatnych, rodzinnych używany jest powszechnie wariant nieoficjalny, czyli język potoczny. Celem moich badań było udowodnienie, iż zachowania niewerbalne występują w obu wariantach polszczyzny. Różni je tylko stopień zintensyfikowania zjawiska oraz świadoma sa- 
mokontrola uczestników interakcji w kontaktach oficjalnych w celu pożądanego wykorzystania mowy ciała.

\section{Cechy komunikacji mówionej twarzą w twarz}

Kazimierz Ożóg i Franciszek Nieckula wyróżniają trzy czynniki, które w zasadniczy sposób determinują komunikację mówioną „twarzą w twarz” (ang. face to face): dialogowość mowy, spontaniczność procesu mówienia, oraz sytuacyjność [Tamże; Nieckuła, 2006, s. 99-113].

Dialogowość mowy wynika $\mathrm{z}$ bezpośredniego kontaktu nadawcy z odbiorcą i polega na przemienności ról mówiącego i słuchającego. Bezpośredni kontakt rozmówców powoduje, że w odmianie ustnej bardzo ważną rolę odgrywają kody: kinezyczny (ruchowy), proksemiczny (związany z odległością między uczestnikami) oraz prozodyczny (czyli wokaliczny).

Spontaniczność tekstów mówionych wynika $\mathrm{z}$ braku ich wcześniejszego przygotowania i konieczności natychmiastowego reagowania. Charakterystyczne dla tych tekstów są tzw. potoki składniowe, czyli ciągi zdań lub wyrażeń luźno ze sobą powiązanych. Kategoria spontaniczności nie obejmuje tekstów ustnych odtwarzanych, np. anegdot, żartów, tekstów folklorystycznych. Są to teksty reprodukowane, gdyż nadawca wcześniej je przygotował lub się ich nauczył. Z wypowiedzią spontaniczną często związana jest korekta, co wiąże się z tym, że słowo biegnie szybciej niż myśl, częściej myślimy o czymś innym, a o czym innym mówimy, zaczynamy pewne zdanie wypowiadać, ale nie kończymy go.

Trzecim czynnikiem wpływającym na kształt wypowiedzi ustnych jest sytuacyjność rozumiana szeroko jako otoczenie aktu mowy. Składa się na nią m.in.: relacja między osobami dialogu (lub polilogu), miejsce aktu mowy, temat dialogu czy parametry socjalne rozmówców: ich wiek, płeć, zawód, pochodzenie, wiedza o świecie, cechy fizyczne i psychiczne. Sytuacyjność aktu mowy sprzyja szerokiemu zastosowaniu elipsy.

Jerzy Bartmiński i Stanisława Niebrzegowska-Bartmińska [2009] wyróżniają dodatkowy element determinujący komunikację mówioną „twarzą w twarz”, czyli gestyczność. I to właśnie gestyczność jest przedmiotem moich badań. Mówienie jest sposobem somatycznego (od grec. soma 'ciało') zachowania się człowieka, a tekst werbalny jest składową tekstu zachowaniowego. Komunikacja face to face pozwala na zaktywizowanie najbardziej elementarnego kodu gestycznego, czyli kodu kinezycznego (grec. kinesis 'ruch'). Elementy gestyczne współtworzą ze słowami jednolity całościowy komunikat ustny.

\section{Typy komunikacji niewerbalnej}

Istnieją trzy główne kody komunikacyjne: kod prozodyczny ('wokaliczny'), kod kinezyczny ('ruchowy') i kod proksemiczny. 
Na kod wokaliczny ${ }^{1}$ składają się: intonacja, siła głosu, przedłużanie niektórych głosek (iloczas), barwa głosu, tempo mówienia czy pauzy. Intonacja to strona rytmiczno-melodyjna wypowiedzi, informuje ona odbiorcę o rozczłonkowaniu wypowiedzi oraz wyraża stosunek emocjonalny mówiącego do wygłaszanego komunikatu. Tempo mówienia, rytm i barwa głosu także przekazują dodatkowe sensy, zwykle natury emocjonalnej.

Proksemika jest związana z odległością między rozmawiającymi. Odległość niewielka jest charakterystyczna dla kontaktu nieoficjalnego, poufnego, z kolei odległość większa charakteryzuje kontakt oficjalny, sformalizowany.

Kodem, któremu w badaniach poświęciłam najwięcej uwagi jest kod kinezyczny. Kinezyka bada, w jaki sposób człowiek za pomocą gestów przekazuje informacje, jest to zatem mowa ciała. Szacuje się, że ludzie za pomocą mowy ciała przekazują około 60-70-ciu procent informacji. W ramach kinezyki wyróżnia się mimikę twarzy (czyli ekspresywność twarzy), ruchy i kierunek spojrzeń, gesty, postawę ciała i haptykę, czyli dotyk. Mimika może służyć różnym celom. Za jej pomocą można intensyfikować uczucia, dezintensyfikować je (pomniejszać), neutralizować (nie okazywać uczuć) lub maskować (tłumić ekspresję).

\section{Cechy i funkcje komunikacji niewerbalnej}

Przejdę teraz do omówienia cech i funkcji komunikacji niewerbalnej. Pierwsze próby opisu i charakterystyki komunikacji niewerbalnej traktowały jąjako „dodatek” do komunikacji słownej. Zatem miała ona niejako ilustrować to, co człowiek określił słowem. Jednak późniejsze badania (z zakresu psychologii, antropologii i etnologii) dowiodły, że bardzo często komunikacja niewerbalna „wyprzedza” komunikację słowną, a nawet może nie mieć z nią nic wspólnego (niespójność gestów i przekazu słownego). Wielu badaczy twierdzi wręcz, że w pierwszych latach swego rozwoju człowiek komunikuje się z otoczeniem głównie kanałem niewerbalnym.

Zachowania niewerbalne cechują się między innymi następującymi właściwościami [Załazińska, 2006, s. 69-70]:

1. Jesteśmy $\mathrm{w}$ nie zaangażowani $\mathrm{w}$ toku konwersacji bez przerwy.

2. Pozostają poza świadomością zachowania — „dzieją się" bez udziału myśli.

3. Gesty samodzielnie nie istnieją, nie mają znaczenia, są zależne od kontekstu, a zatem nie są konwencjonalne. Dodatkowo są one uwarunkowane kulturowo!

4. Są zintegrowane z zachowaniami.

${ }^{1}$ Robert Andrzej Dul w artykule pt.: Komunikacja niewerbalna w teorii i badaniach stosuje określenie parajęzyka, które jest szersze znaczeniowo niż pojęcie subkodu wokalicznego. Parajęzyk obejmuje dwie kategorie. Pierwszą są właściwości głosowe, na które składają się te same elementy, co na subkod wokaliczny u Ożoga. Drugą kategorią są niewerbalne wokalizacje, obejmujące trzy typy zjawisk dźwiękowych: 1) charakteryzatory wokalne, np. śmiech, płacz, gwizd itp.; 2) wokalne kwalifikatory, np. intensywność głosu, jego rozciągłość itp.; 3) wokalne oddzielniki, czyli dźwięki lub okresy milczenia występujące między wypowiadanymi słowami i zdaniami, np. „hmm”, „tss”, „,bzz” itp. 
Jan Andrzej Dul podstawowych przyczyn użycia zachowań niewerbalnych w procesie komunikacji upatruje w ograniczoności i niedostateczności dostosowania języka do wyrażania niektórych treści i doświadczeń o charakterze emocjonalnym bądź osobistym. W języku brakuje niekiedy określeń dla jakichś zjawisk, uczuć — wówczas kanałem przekazu informacji stają się zachowania niewerbalne, posiadające ogromną zdolność komunikacji. Dul [1995, s. 43-68] jako zasadnicze funkcje komunikacji niewerbalnej podaje:

$>$ preartykulacja idei i znaczeń,

$>$ inicjowanie i przekaz informacji,

$>$ pobudzanie wyobraźni,

$>$ maskowanie uczuć,

$>$ przekaz treści ukrytych i subtelnych.

D. Leathers [2007, s. 33-37] wskazuje zaś na takie funkcje komunikatów niewerbalnych, jak:

$>$ przekazywanie informacji,

$>$ regulowanie interakcji,

$>$ wyrażanie emocji,

$>$ tworzenie metakomunikacji,

$>$ kontrolowanie sytuacji społecznych,

$>$ kształtowanie i kierowanie wrażeniami.

\section{Typologia gestów}

Przedstawię teraz typologię gestów, według której porządkowałam zgromadzony materiał i będzie to pierwsza semiotyczna klasyfikacja gestów, przeprowadzona w 1969 r. przez Paula Ekmana i Wallace'a Friesena, a opisana przez Anetę Załazińską [2006]. Według niej wyróżniamy:

1. Emblematy, które mogą zastąpić elementy lingwistyczne, będące niewerbalnymi substytutami konkretnych słów (np. machamy komuś zamiast powiedzieć „do widzenia”).

a) Wypowiedź prowadzącego - Roberta Kantereita z odcinka pt. Choroba pocatunków z dn. 10.01.2011 r.: Ciii... Cicho... Weź łyka herbaty... GEST: palec wskazujący przyciąga do ust i kieruje gest do współprowadzącej program. ZNACZENIE: konwencjonalny gest nakazujący zachowanie ciszy; ma bezpośredni werbalny odpowiednik - słowo cisza.

b) Wypowiedź gościa - Emiliana Kamińskiego z odcinka pt. Koniec zdobywania po ślubie? z dn. 24.01.2011 r.: Na kolana, chodź..., siadaj na kolana. GEST: przywoływanie palcami dłoni (kogoś). ZNACZENIE: niewerbalny odpowiednik słów chodź, przyjdź. 
2. Ilustratory, które wspomagają słowa, oferują komentarz do wypowiadanych słów, stanowią formę wizualizacji rzeczy (np. mówię idź prosto i wskazuję palcem).

a) Wypowiedź psycholog z Fundacji Dzieciom "Zdążyć z Pomocą" — Karoliny Czynsz-Grabiec z odcinku pt. Stuprocentowy rodzic. Stuprocentowy pracownik $\mathrm{z}$ dn. 09.12.2010 r.: A więc on musi się rozpychać lokciami, a przez to uczy się bardzo wielu rzeczy. GEST: ruch zgiętymi w łokciach rękami od siebie ,na zewnątrz”; ZNACZENIE: gest obrazujący/ilustrujący wypowiadane słowa, redundantny wobec komunikatu.

b) Wypowiedź gościa - Anny Marii Wesołowskiej z odcinku pt. Prawny aspekt nastoletnich ciąz z dn. 18.12.2010 r.: Od trzynastego roku życia u nas dziecko odpowiada przed sadem. GEST: palec wskazujący uniesiony w górę, na wysokość głowy. ZNACZENIE: szczególne podkreślenie informacji, uznanie jej za ważną i zasługującą na wyróżnienie spośród innych. Jest to przykład ilustratora mentalnego, czyli obrazującego abstrakty, tworzącego płaszczyznę ideacyjną dialogu [Załazińska, 2006, s. 117-118]. Dzięki takim zachowaniom niewerbalnym myśli zyskują status rzeczy fizycznej, materialnej, są także komunikowane ludzkie idee.

3. Wskaźniki emocji, ujawniają przeżywane stany emocjonalne. Najmocniej są wyrażane za pomocą układu mimicznego lub odpowiedniego ułożenia i pozycji ciała.

a) Wypowiedź prowadzącego - Marcina Prokopa z odcinku pt. Ratunku! Pracuje z samymi kobietami z dn.18.01.2011 r.: Ja bym zabrat glos natychmiast! GEST: uniesienie obu otwartych dłoni do góry, na wysokość głowy, palce wyprostowane (gest ,poddawania się”). ZNACZENIE: tworzenie z rąk bariery, odsuwanie czegoś, podkreślenie dystansu mówiącego wobec tematu. W tym przypadku gest nie jest spójny z wypowiedzią - wręcz jest jej zaprzeczeniem. Świadczy o rozbieżności wypowiedzi i stanu faktycznego.

b) Wypowiedź prowadzącego - Marcina Prokopa z odcinku pt. Miłość na odległość z dn. 19.11.2010 r.: Ale okazja czyni złodzieja, przepraszam! GEST: uderza wewnętrzną stroną otwartych dłoni o swoje kolana, ironicznie się uśmiecha. ZNACZENIE: przybija jakby wypowiadane słowa, potwierdza ich słuszność, wyraża pewność siebie, a jednocześnie swój sceptyczny stosunek wobec słów rozmówcy.

4. Regulatory konwersacji, regulują i organizują interakcję i odnoszą się do sposobów używania całego ciała (np. dotykamy kogoś, by zwrócić jego uwagę); służą zatem sterowaniu rozpoczęciem, czasem trwania i zakończeniem wypowiedzi lub rozmowy. 
a) Wypowiedź gościa - Marcina Żebrowskiego z odcinku pt.: Miłość na odległość z dn. 19.11.2010 r.: I podczas tych dni: co będziesz robit? Jaki masz następny live? GEST: Prowadząca - Dorota Wellman podnosi dwa złączone palce do góry. ZNACZENIE: jako osoba słuchająca i chcąca zabrać głos w rozmowie, sygnalizuje chęć zabrania głosu.

b) Wypowiedź prowadzącej - Doroty Wellman z odcinku pt. Dla kobiet najważniejsze sa pieniądze z dn. 23.11.2010 r.: Jeśli mogę do Matgosi Rozenek. Malgosiu, ty mialaś bardzo dobra pracę, byłaś prawnikiem $w$ bardzo dobrej kancelarii i w pewnym momencie życia, z powodu wielkiej mitości, podjętaś decyzję, że zostaniesz w domu. GEST: Palec wskazujący skierowany w stronę konkretnej rozmówczyni. ZNACZENIE: Gest potwierdzający werbalny zwrot do gościa, informujący innych gości o tym, kto jest konkretnym adresatem oraz obligujący wskazaną Małgorzatę Rozenek do skupienia uwagi na wysyłanym komunikacie słownym, a także do nawiązania i podtrzymania kontaktu.

5. Adaptatory, które służą do osiągnięcia najbardziej komfortowej dla mówiącego sytuacji konwersacyjnej, świadczą o jego nastawieniu wobec danej sytuacji. W ich ramach można wyróżnić autoadaptatory, czyli zachowania prowadzące do uregulowania napięcia psychicznego nadawcy. (np. skoro puka długopisem / macha nogą — jest zdenerwowany).

a) Wypowiedź prowadzącej - Doroty Wellman z odcinku pt. Ratunku! Pracuje z samymi kobietami z dn.18.01.2011 r.: Marku, od ciebie zaczniemy, [...] bo rzeczywiście wszedteś do gniazda os, same kobiety. GEST: Gość — adresat wypowiedzi (tj. Marek) reaguje na zwrot prowadzącej i zmienia pozycję: z wyprostowanej pozycji siedzącej, pochyla się w stronę prowadzącej i opiera ręce na kolanach. ZNACZENIE: Wyraz zainteresowania i zaangażowania $\mathrm{w}$ rozmowę.

b) Wypowiedź prowadzącego - Roberta Kantereita z odcinku pt. Koniec zdobywania po ślubie? z dn. 24.01.2011 r.: Co moglibyśmy zrobić, żeby sprawić kobiecie przyjemność? GEST: Jeden z zaproszonych gości drapie się po policzku, zmienia pozycję ciała na bardziej komfortową, wygodnie usadza się na kanapie, na słowa prowadzącego reaguje uśmiechem. ZNACZENIE: gość szuka najbardziej komfortowej pozycji, która pozwoli mu na odpowiednie zaangażowanie $\mathrm{w}$ interesujący go temat rozmowy.

\section{Makro- i mikrosytuacja wywiadu telewizyjnego}

Po wykazaniu nieodłączności kodu niewerbalnego od komunikacji werbalnej, przejdę do omówienia zależności między specyfiką programu Dzień Dobry TVN w kontekście makro- i mikrosytuacji wywiadu telewizyjnego. Wywiad jest przeka- 
zem telewizyjnym. Na sytuację telewizyjną składają się: sytuacja traktowana globalnie, czyli makrosytuacja, i sytuacja traktowana lokalnie, czyli mikrosytuacja. Elementy makrosytuacji to: nadawca medialny (stacja telewizyjna lub konkretna redakcja programu, bądź osoby w nim uczestniczące, czyli dziennikarz i zaproszony gość), odbiorca masowy i zachodzące między nimi relacje (podział ról nadawca - odbiorca). Stacja telewizyjna to zarówno urządzenia techniczne, nakłady finansowe, jak i liczny personel czy prawne ramy działania. Nadawca zespołowy, czyli redakcja to wszyscy, którzy mają wpływ na decyzję o powstaniu przekazu i jego udostępnianiu. Jednak musi ona wykorzystywać instytucję medialną, ponieważ ta posiada potencjał techniczny. Nadawcą indywidualnym jest dziennikarz/ prezenter, również nieposiadający potencjału technicznego, zatem on także musi współpracować z instytucją medialną. Odbiorca jest rozumiany jako zespół osób składających się z widzów określonych programów [Sobczak, 2006, s. 46-47].

Mikrosytuację zaś tworzą osoby w studiu, prowadzące rozmowę przed kamerami i wchodzące $\mathrm{w}$ relacje nadawania i odbierania. Mikrosytuacja jest wpisana w makrosytuację telewizyjną, czego wszyscy w studiu są świadomi i co ma niemały wpływ na przekaz.

Po rozpoznaniu sytuacji, jakie mogą się tworzyć w studiu lub w szerszym układzie nadawczo-odbiorczym, przejdę do omówienia specyfiki gatunkowej programu Dzień Dobry TVN.

\subsection{Specyfika programu Dzień Dobry TVN}

Dzień Dobry TVN to poranny magazyn (morning show) telewizji TVN, nadawany codziennie między 8:30 a 11:00. Trzon programu stanowią rozmowy z zaproszonymi gośćmi. Inne stałe elementy to kącik kulinarny, relacje reporterów, cykliczne bloki i prognoza pogody. DD TVN zadebiutowało we wrześniu 2005 roku.

Prymarnie programy telewizyjne należą do sytuacji oficjalnych, co wynika z właściwości komunikacji masowej i roli dziennikarza, jednak w przypadku magazynów śniadaniowych strategia mediów zakłada przełamanie konwencji. Nowa strategia kładzie nacisk przede wszystkim na przyciągnięcie widza, zatem mamy do czynienia z wtórną nieoficjalnością czy też wtórną spontanicznością.

Umberto Eco [999, s. 174] uważa, że żyjemy w epoce neotelewizji, której ważną cechą jest zachęcenie widza do aktywności, zerwanie z nadrzędnością nadawcy w stosunku do widza, co ma prowadzić do powstania ,przestrzeni wspólnego biesiadowania”. Prowadzący stają się bliscy widzowi, nie dominują, są swobodni. Panuje familiarna forma kontaktu. Konstrukcję i tematykę tego typu programów, można opisać stosując takie pojęcia, jak infotainment (hybryda informacji i rozrywki), niusyzacja, czy tabloidyzacja mediów. Stąd swoboda w sferze zachowań prezenterów i gości, a co się z tym wiąże, szeroka gama gestów i innych subkodów komunikacyjnych (np. postaw), będących przedmiotem moich badań. 


\section{Zakończenie}

Badania dotyczące zachowań niewerbalnych nie są w polskim językoznawstwie mocno ugruntowane, warto jednak zauważyć, że już w czasach starożytnych Kwintylian przekonywał o wartości gestów w interakcji werbalnej. Analiza materiału potwierdziła cel moich badań, iż gesty i słowa stanowią całość znaczeniowo-komunikacyjną i należy je badać jednocześnie podczas zdarzenia mownego. Gesty są ściśle zintegrowane z myślami mówiącego. Niekiedy zdarza się tak, że zachowanie niewerbalne jest niespójne z wypowiadanymi słowami. Świadczy to o zatajonych, prywatnych intencjach mówiącego, który ma na celu ukrycie jakichś informacji, jednak gest demaskuje jego prawdziwy stosunek do poruszanego tematu. Taki nadawca staje się wówczas osobą nie do końca wiarygodną. Ze względu na to, że prowadzący kreują program na sytuacje wtórnie nieoficjalne, co zresztą wynika $\mathrm{z}$ konwencji magazynu porannego, możliwe jest w nim aż takie nagromadzenie zachowań niewerbalnych. Ponadto uczestnicy wybranych przeze mnie programów w większości nie byli debiutantami przed kamerami telewizyjnymi, dlatego ich gesty były naturalne i spontaniczne, zwłaszcza gdy angażowali się emocjonalnie w przebieg rozmowy. Typ programu nie ograniczał wykonywanych przez nich sygnałów ilościowo ani jakościowo. Toteż badanie zagadnienia komunikacji niewerbalnej na podstawie $D D T V N$ dostarczyło tylu różnych przykładów. Gdyby konwencja telewizji śniadaniowej nie zakładała wtórnej spontaniczności, to uczestnicy interakcji zdecydowanie rygorystyczniej staraliby się panować nad swoimi zachowaniami. Jednak bardziej formalne wystąpienia rozmówców pozbawiłyby program ,,przestrzeni wspólnego biesiadowania”, a zatem zaburzyłyby formułę telewizji śniadaniowej.

Należy także podkreślić, iż gesty są uwarunkowane kontekstowo i kulturowo. Nie można ich uniwersalizować, ponieważ w zależności od kraju dany gest często przywołuje zupełnie inne konotacje. Nawet w ramach określonego języka czy kręgu kulturowego nie jest możliwe stworzenie jednoznacznego, pełnego inwentarza gestów, można jedynie dążyć do wydobycia pewnych dominant lub dystynktywnych ruchów w gestach o określonych funkcjach. 


\section{Bibliografia}

AntAs J., 1996, Gest, mowa, a myśl [w:] Językowa kategoryzacja świata, Grzegorczykowa R., Pajdzińska A. (red.), Lublin, s.71-95.

Axtell R. E., 2007, Powinności i tabu na całym świecie. Ryzykowny język, czyli czyny mówia glośniej od stów — czasem zupetnie nie to, co trzeba [w:] Mosty zamiast murów, Stewart J. (red.), Warszawa, s. 134-141.

BARTMiŃSKi J., NieBrZEgOwSKA-BARTMIŃSKA B., 2009, Cechy tekstów ustnych charakterystyka zbiorcza [w:] tychże, Tekstologia, Warszawa, s. 99-106.

Dur R. A., 1995, Komunikacja niewerbalna w teorii i badaniach [w:] Komunikacja międzykulturowa, Kapciak A., Korporowicz L., Tyszka A. (red.), Warszawa, s. 43-68.

Eco U., 1999, Semiologia życia codziennego, Warszawa.

JASKÓŁKA A., 2007, Mowa ciała, Kielce.

KrupsKa-PereK A., 2001, Kod językowy a inne składniki aktu komunikacji bezpośredniej [w:] Język w komunikacji, Habrajska G. (red.), t.1, Łódź, s. 155-163.

Leathers D. G. 2007, Komunikacja niewerbalna, Warszawa, s. 33- 37.

NieCKula F., 2006, Język ustny a język pisany [w:] Współczesny język polski, Bartmiński J. (red.), 2006, s. 99-113.

OżóG K., 2006, Ustna odmiana języka ogólnego [w:] Współczesny język polski, Bartmiński J. (red.), 2006, s.85-98.

Soвczak B., 2006, Makro- i mikrosytuacja wywiadu telewizyjnego [w:] tejże, Wywiad telewizyjny na żywo. Charakterystyka gatunku, Poznań, s. 46-47.

ZaŁAZIŃSKA A., 2006, Niewerbalna struktura dialogu. W poszukiwaniu polskich wzorców narracyjnych i interakcyjnych zachowań komunikacyjnych, Kraków.

—, 2001, Schematy myśli wyrażane w gestach, Kraków. 